\title{
Solubility of Palladium in Alumina-Iron Silicate Melts
}

\author{
KATRI AVARMAA (D), ${ }^{1}$ LASSI KLEMETTINEN (i), ${ }^{1}$ HUGH O'BRIEN $\mathbb{}$ (1) ${ }^{2}$ \\ ARI JOKILAAKSO (D), ${ }^{1}$ DANIEL LINDBERG ${ }^{1},{ }^{1}$ \\ and PEKKA TASKINEN (i) ${ }^{1,3}$
}

\begin{abstract}
1.-Department of Chemical and Metallurgical Engineering, School of Chemical Engineering, Aalto University, P.O Box 16100, 00076 Aalto, Finland. 2.-Geological Survey of Finland, Vuorimiehentie 2, 02150 Espoo, Finland. 3.—e-mail: pekka.taskinen@aalto.fi
\end{abstract}

\begin{abstract}
Dissolution and solubility of palladium in iron silicate melts saturated with alumina-iron spinel at $1300^{\circ} \mathrm{C}$ has been measured using an equilibration-drop quenching technique combined with electron probe microanalysis and laser ablation-inductive coupled plasma-mass spectrometry analysis from polished sections. Composition of the resulting Fe-Pd alloy allowed estimation of the activity of palladium at different oxygen partial pressures, and, thus, the solubilities of palladium in the studied slags in conditions typical of copper and nickel smelting as well as slag cleaning at $p_{\mathrm{O} 2}=10^{-5}$ to $10^{-10}$ atm. The mechanism of palladium dissolution in the studied iron silicate slags was oxidation by formation of the monovalent oxide species $\mathrm{PdO}_{0.5}$ over the entire oxygen activity range of this study. Testing the applicability of the various palladium isotopes for quantitative analyses of $\mathrm{Pd}$ in these types of matrices resulted in a good fit of measured concentrations of ${ }^{104} \mathrm{Pd}$ and ${ }^{105} \mathrm{Pd}$ with interference-corrected ${ }^{106} \mathrm{Pd}$ and ${ }^{108} \mathrm{Pd}$.
\end{abstract}

\section{INTRODUCTION}

Palladium is one of the most important precious metals used in electrical and electronic equipment, as well as playing a critical role in catalytic converters. Palladium and platinum have similar properties, and thus, depending on their prices in metal exchanges, their use in the major application fields may change from platinum to palladium and back to platinum in a cyclical way. In general, palladium is a much less well-studied platinum group metal (PGM) in geochemical and metallurgical processes than platinum. Sullivan et al. ${ }^{1}$ recently compiled the available solubility data for palladium in silicate melts as a function of oxygen partial pressure. They also summarized most of the earlier studies in geochemistry as a function of temperature and pressure.

Nishijima and Yamaguchi ${ }^{2}$ determined PGM distributions between ternary $\mathrm{Al}_{2} \mathrm{O}_{3}-\mathrm{CaO}-\mathrm{SiO}_{2}$ slags at copper saturation and $1450^{\circ} \mathrm{C}$, measuring the oxygen activities with an EMF cell. Their distribution results were essentially independent of the $(\mathrm{CaO}+$

(Received December 17, 2020; accepted March 29, 2021; published online April 23, 2021)
$\mathrm{MgO}) /\left(\mathrm{CaO}+\mathrm{MgO}+\mathrm{SiO}_{2}\right) \quad$ ratio (w/w). Shuva et al. ${ }^{3}$, Avarmaa et al. ${ }^{4,5}$ and Sukhomlinov et al. ${ }^{6}$ determined the distribution coefficients of palladium between selected secondary copper smelting slags and a copper alloy. Yamaguchi ${ }^{7,8}$ measured palladium distributions between copper and $\mathrm{CaO}$ $\mathrm{FeO}_{x}$ slags at $1300^{\circ} \mathrm{C}$ and $\mathrm{MgO}$ saturation. Henao et al. ${ }^{9}$ carried out measurements on PGMs as trace elements in a copper matte-silicate slag system at $\mathrm{MgO}$ saturation at $1300^{\circ} \mathrm{C}$. Avarmaa et al. ${ }^{10}$ and Piskunen et al. ${ }^{11}$ studied palladium distributions in copper and nickel matte smelting conditions at silica saturation, and conducted direct phase composition measurements with laser ablation-inductive coupled plasma-mass spectrometry (LA-ICPMS).

Tomiska ${ }^{12}$ summarized the previous experimental data on the Fe-Pd system and carried out Knudsen cell measurements on ternary $\mathrm{Au}-\mathrm{Fe}-\mathrm{Pd}$ alloys. Ghosh et al. ${ }^{13}$ carried out a critical thermodynamic assessment of the Fe-Pd alloy system using the available thermodynamic and phase equilibrium information.

This study experimentally investigated palladium behavior in copper smelting and converting conditions $\left(1300^{\circ} \mathrm{C}, p_{\mathrm{O} 2}=10^{-10}-10^{-5} \mathrm{~atm}\right)$ without the 
presence of copper. The simultaneous presence of copper and palladium in LA-ICP-MS measurements is a demanding task, as copper argide $\left({ }^{65} \mathrm{Cu}^{40} \mathrm{Ar}^{+}\right)$, potentially formed by the $\mathrm{Ar} \mathrm{ICP}^{14}$ in copperbearing systems, has almost the same molar mass as the ${ }^{105} \mathrm{Pd}$ isotope and they are therefore impossible to separate by a mass spectrometer running at low mass resolution. This problematic mass interference was a driver for the current measurements on $\mathrm{Cu}$-free experiments, providing higher accuracy $\mathrm{Pd}$ distribution coefficient determinations with a pure palladium equilibrium phase instead of a dilute copper alloy ${ }^{4-6}$ or copper-bearing matte ${ }^{10,11}$. Moreover, as PGMs are also recovered via metallic iron-slag systems, ${ }^{15}$ this study also provides valuable data and information for those technologies.

\section{EXPERIMENTAL}

The experimental technique involved sample equilibration at a controlled temperature, $1300 \pm 3^{\circ} \mathrm{C}$, and in a flowing gas atmosphere, followed by rapid quenching and direct elemental analyses of the equilibrium phases with EPMA (electron probe microanalysis) and LA-ICP-MS from polished sections. The materials used in the experiments have been collected in Table $\mathrm{S} 1$ of the online Electronic Supplementary Material file. They were mixed and homogenized by grinding in an agate mortar with a metal alloy-to-slag ratio of $1: 9$ and a $\mathrm{Fe} / \mathrm{SiO}_{2}$ ratio of $1.3(\mathrm{w} / \mathrm{w})$ in slag. The $\mathrm{CO}-\mathrm{CO}_{2}$ gas mixtures used to generate the different oxygen partial pressures at $1300^{\circ} \mathrm{C}$ were controlled using thermal mass flow controllers (DFC 26; Aalborg, USA) of different flow ranges, with an accuracy of $\pm 1 \%$ of full range. The gases were supplied by AGA-Linde (Finland) with purities of 99.97 vol.\% $\mathrm{CO}$ and 99.9992 vol.\% $\mathrm{CO}_{2}$.
The details of the experimental furnace and the gas train have been described earlier. ${ }^{16,17}$ This study continues the PGM solubility studies in a similar Fe alloy-slag system with the same experimental arrangement and procedure as previously published for platinum. ${ }^{16}$ The sample and an alumina crucible as the sample holder in the hot zone of the experimental furnace are shown in Fig. 1(a). All the other experimental details, including the furnace, sample mass, equilibration time series, and analytical equipment, are available in the previous publication regarding platinum solubility in alumina-iron silicate slag. ${ }^{16}$ All the presented experiments were equilibrated for $48 \mathrm{~h}$. A typical microstructure of the equilibrated-quenched sample is shown in Fig. 1(b).

\section{SAMPLE CHARACTERIZATION}

The elemental compositions of the quenched metal and slag were analyzed with EPMA, of which the analytical details have been presented earlier. ${ }^{16}$ The only change was that pure $\mathrm{Pd}$ was used as a standard for analyzing $\mathrm{Pd} L \alpha$ peaks in the $\mathrm{Pd}-\mathrm{Fe}$ alloy, as opposed to pure $\mathrm{Pt}$ for $\mathrm{Pt} \mathrm{L} \alpha$. The averages of eight EPMA points have been reported as well as their standard deviations. The slag composition results are presented in more detail elsewhere. ${ }^{18}$

The slag and spinel phases were also analyzed by LA-ICP-MS, since the concentrations of palladium were below the detection limit of EPMA. The details of this equipment have also been presented earlier. ${ }^{16}$ For slag analysis, NIST 612 SRM $^{19}$ was employed as the external standard and ${ }^{29} \mathrm{Si}$ as the internal standard. NIST 610, BHVO-20, and BCR$2 \mathrm{G}^{19,20}$ were analyzed as unknowns for monitoring the analysis accuracy. For spinels, GSD-1G ${ }^{20}$ was chosen as the external standard and ${ }^{57} \mathrm{Fe}$ as the internal. The $\mathrm{Pd}$ concentration in GSD-1G was determined by analyzing this standard material as
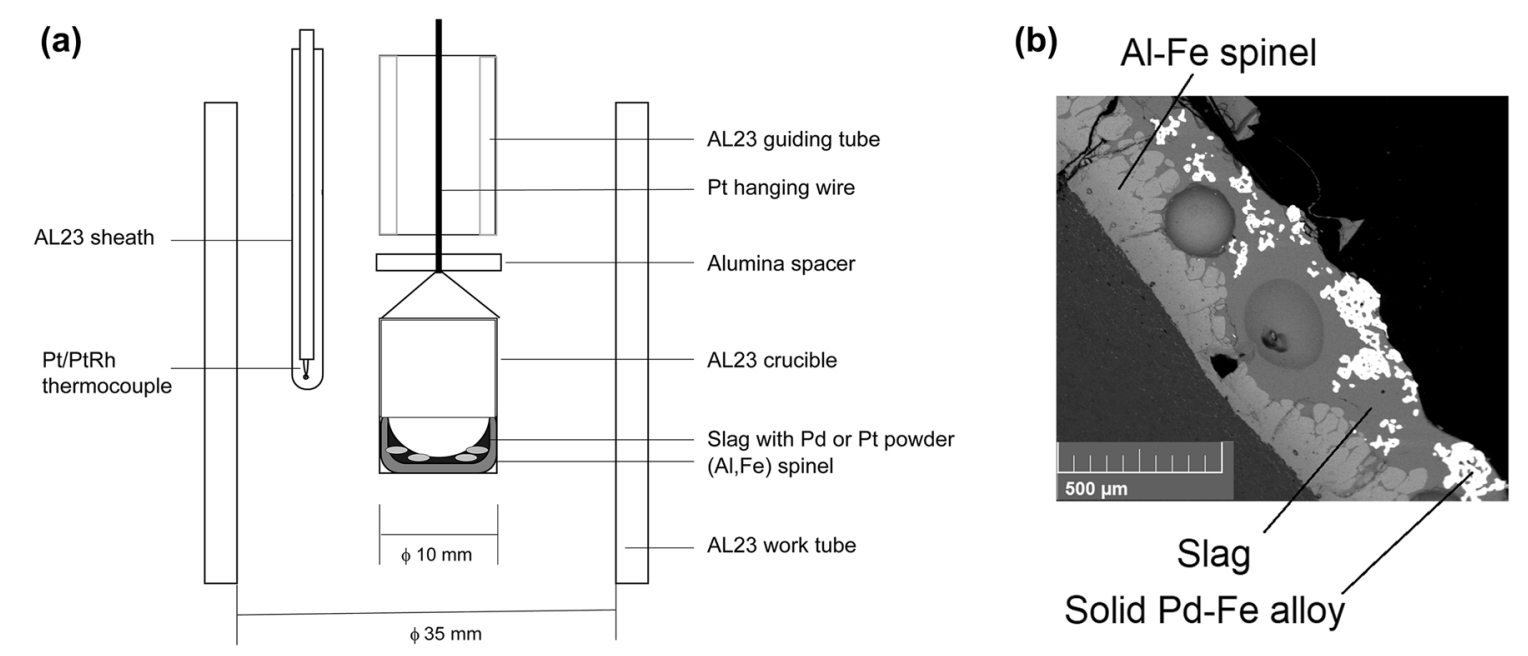

Fig. 1. (a) Schematic of the hot-zone of the experimental furnace with the measuring thermocouple next to the sample. AL23 indicates ceramic DEGUSSIT AL23 $\left(\mathrm{Al}_{2} \mathrm{O}_{3}\right)$ by Friatec (today Kyocera Fineceramics $\mathrm{GmbH}$ ). (b) A typical microstructure of sample taken with SEM-BSE. 
Table I. Re-analyzed palladium concentrations in slags for different isotopes

\begin{tabular}{|c|c|c|c|c|c|}
\hline Sample & $\mathbf{p}_{\mathrm{O} 2} / \mathbf{a t m}$ & ${ }^{104} \mathbf{P d}$ & ${ }^{105} \mathbf{P d}$ & ${ }^{106} \mathbf{P d}^{\mathbf{a}}$ & ${ }^{108} \mathbf{P d}^{\mathrm{a}}$ \\
\hline Pd8 & $10^{-5}$ & $70.4 \pm 3.1$ & $67.9 \pm 1.8$ & $58.9 \pm 2.3$ & $62.3 \pm 2.2$ \\
\hline $\operatorname{Pd} 10$ & $10^{-6}$ & $36.5 \pm 2.5$ & $34.0 \pm 2.7$ & $28.1 \pm 1.5$ & $31.3 \pm 1.6$ \\
\hline $\mathrm{Pd} 6$ & $10^{-7}$ & $16.8 \pm 1.4$ & $16.9 \pm 0.8$ & $16.4 \pm 0.6$ & $15.0 \pm 0.7$ \\
\hline Pd1 & $10^{-9}$ & $2.4 \pm 0.3$ & $2.1 \pm 0.3$ & $2.7 \pm 0.3$ & $2.6 \pm 0.4$ \\
\hline $\mathrm{Pd} 3$ & $10^{-10}$ & $0.8 \pm 0.4$ & $1.0 \pm 0.2$ & $0.9 \pm 0.2$ & $0.8 \pm 0.2$ \\
\hline
\end{tabular}

${ }^{a}$ Values achieved by using correction formulas ${ }^{4,23}$.

Table II. The experimental data of this study by LA-ICP-MS (slag) and EPMA (alloy)

\begin{tabular}{|c|c|c|c|c|}
\hline \multirow[b]{2}{*}{ Sample } & \multirow{2}{*}{$\frac{\log _{10} p_{O 2}}{\operatorname{atm}}$} & \multirow{2}{*}{$\frac{\text { Slag }}{(\mathbf{P d} / \mathbf{p p m w})}$} & \multicolumn{2}{|c|}{ Pd-Fe alloy } \\
\hline & & & (Pd/wt.\%) & (Fe/wt.\%) \\
\hline $\operatorname{Pd} 7$ & -5.0 & $89.8 \pm 1.2$ & $95.56 \pm 0.16$ & $4.44 \pm 0.06$ \\
\hline $\mathrm{Pd} 8$ & -5.0 & $71.6 \pm 1.7$ & $96.48 \pm 0.18$ & $3.52 \pm 0.10$ \\
\hline $\operatorname{Pd} 10$ & -6.0 & $32.7 \pm 1.7$ & $92.43 \pm 0.39$ & $7.57 \pm 0.16$ \\
\hline Pd5 & -7.0 & $14.3 \pm 0.2$ & $90.63 \pm 0.16$ & $9.37 \pm 0.05$ \\
\hline Pd6 & -7.0 & $17.5 \pm 0.2$ & $90.50 \pm 0.17$ & $9.50 \pm 0.06$ \\
\hline Pd1 & -9.0 & $2.7 \pm 0.1$ & $81.76 \pm 0.34$ & $18.24 \pm 0.08$ \\
\hline $\mathrm{Pd} 2$ & -9.0 & $3.9 \pm 0.3$ & $83.90 \pm 0.33$ & $16.10 \pm 0.10$ \\
\hline $\mathrm{Pd} 3$ & -10.0 & $0.9 \pm 0.1$ & $78.81 \pm 0.29$ & $21.19 \pm 0.11$ \\
\hline Pd9 & -10.0 & $1.2 \pm 0.1$ & $75.91 \pm 0.27$ & $24.09 \pm 0.16$ \\
\hline
\end{tabular}

an unknown, using NIST 612 as an external standard and ${ }^{57} \mathrm{Fe}$ as internal. The value obtained for $\mathrm{Pd}$ concentration was $33 \mathrm{ppm}$. The Glitter software package ${ }^{21}$ was applied for the raw data processing, i.e., the baseline reduction and quantifications.

The palladium concentrations were measured for all the existing isotopes ${ }^{104} \mathrm{Pd},{ }^{105} \mathrm{Pd},{ }^{106} \mathrm{Pd},{ }^{108} \mathrm{Pd}$, and ${ }^{110} \mathrm{Pd}$ by the LA-ICP-MS technique. In this study, due to the absence of copper in the experimental charges, the isotopes ${ }^{104} \mathrm{Pd}$ and ${ }^{105} \mathrm{Pd}$ provide interference-free measurements and could be used, as such, to present the final results. The interference caused by the formation of ${ }^{89} \mathrm{Y}^{16} \mathrm{O}^{+}$for ${ }^{105} \mathrm{Pd}$ was evaluated negligible $(<2 \%)$ as the concentration of $Y$ in NIST612 standard is only 38.3 ppmw $(Y / \mathrm{Pd}$ ratio $=36.5)$, and its influence was evaluated as $20 \%$ of the counts measured on ${ }^{105} \mathrm{Pd}$ when using high $Y / P d$ ratio (381.8) standard NIST610. ${ }^{22}$ The ${ }^{106} \mathrm{Pd},{ }^{108} \mathrm{Pd}$, and ${ }^{110} \mathrm{Pd}$ isotopes have isobaric interferences from $\mathrm{Cd}$-isotopes when using NIST 612 SRM as the primary standard material and additionally ${ }^{94} \mathrm{Zr}^{16} \mathrm{O}^{+}$for ${ }^{110} \mathrm{Pd} .{ }^{23}$ Because $\mathrm{Cd}$ exists in the standards, but not in the experimental samples, the measured palladium results based on the ${ }^{106} \mathrm{Pd}$ and ${ }^{108} \mathrm{Pd}$ isotopes were lower than the true concentrations. Nevertheless, results for isotopes of ${ }^{106} \mathrm{Pd}$ and ${ }^{108} \mathrm{Pd}$ can be interference-corrected by using formulae presented in the literature. ${ }^{4,24}$ Consequently, selected samples were re-analyzed for a range of $\mathrm{Pd}$ and $\mathrm{Cd}$ isotopes to allow correction of ${ }^{106} \mathrm{Pd}$ and ${ }^{108} \mathrm{Pd}$ and to verify the consistency of calculated $\mathrm{Pd}$ concentrations based on four different Pd isotopes (Table I).

As can be seen in Table I, palladium concentrations in slags based on different isotope measurements are internally consistent. This provides a good indication that the use of corrected ${ }^{106} \mathrm{Pd}$ and ${ }^{108} \mathrm{Pd}$ isotopes are applicable for systems when there are interference problems with the ${ }^{104} \mathrm{Pd}$ and ${ }^{105} \mathrm{Pd}$ isotopes, such as copper-containing slags $\left({ }^{65} \mathrm{Cu}^{40} \mathrm{Ar}^{+}\right)$with the ${ }^{105} \mathrm{Pd}$ isotope. ${ }^{4}$ In this study, we employed the ${ }^{105} \mathrm{Pd}$ isotope results, as this isotope has a higher natural abundance, of $22.33 \%$, ${ }^{25}$ than ${ }^{104} \mathrm{Pd}(11 \%)$. The detection limits for the elements studied with EPMA and LA-ICPMS obtained in this study have been summarized in Table S2 of the Electronic Supplementary Material file.

Only minor heterogeneities in some time-resolved MS spectra were observed in the samples, as indicated by the experimental uncertainties collected in Tables I and II. The time-resolved MSsignal profiles were generally smooth as a function of time, as indicated in Fig. 2; only occasional spikes were present. This indicates that only a few nanonuggets of palladium ${ }^{26}$ were possibly present in the iron silicate slags prior to or after the quench. 


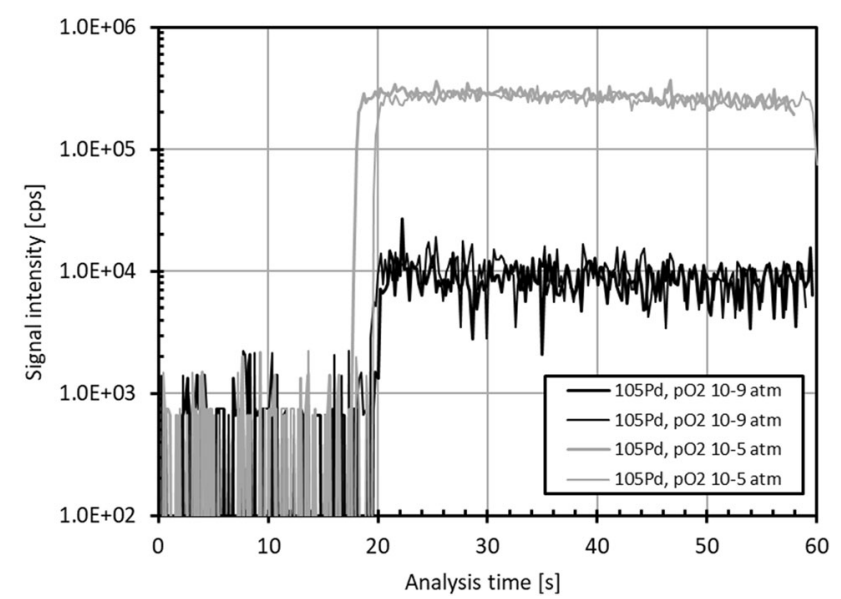

Fig. 2. Time-resolved analysis signal profiles for palladium $\left({ }^{105} \mathrm{Pd}\right)$ of two LA-ICP-MS measurement points on slags equilibrated at $10^{-5}$ and $10^{-9}$ atm oxygen partial pressures and $1300^{\circ} \mathrm{C}$; the ablation started approximately at $20 \mathrm{~s}$.

\section{RESULTS AND DISCUSSION}

The primary concentration data for palladium in the slag based on ${ }^{105} \mathrm{Pd}$ measurements are shown in Table II and Fig. 3 as a function of oxygen partial pressure. The vertical error bars show the experimental analytical standard deviations $( \pm 1 \sigma)$ calculated from the independent LA-ICP-MS analysis points of each sample, and the horizontal error bars for $\log _{10} \mathrm{p}_{\mathrm{O} 2}$ as a fixed value of \pm 0.2 based on the full range accuracy of mass flow controllers and gas flow rates presented earlier. ${ }^{16}$ The re-analyzed sample results for ${ }^{105} \mathrm{Pd}$ (see Table I) fit well with the primary results measured and shown in Table II.

Due to the dissolution of iron during equilibration, the composition of the palladium alloy was strongly affected by the prevailing oxygen partial pressure of the system. The EPMA data of the solid alloy are shown in Table II and Fig. 4. Using these data, the solubility of palladium (i.e., in equilibrium with pure metal and excluding the effects of dissolved iron) in the slag can be evaluated using the relationship:

$$
* c(\mathrm{Pd})=c(\mathrm{Pd}) / a[\mathrm{Pd}]
$$

where $a[\mathrm{Pd}]$ is the activity of palladium in the metallic Fe-Pd alloy, ${ }^{13}$ referred to pure solid palladium, and $c(\mathrm{Pd})$ is the measured concentration of palladium in the slag at that activity. This corrected chemical solubility of palladium $[* c(\mathrm{Pd})]$ in alumina spinel saturated iron silicate melt at $1300^{\circ} \mathrm{C}$ as a function of the oxygen partial pressure is presented in Fig. 5.

Figure 5 shows that the solubility of palladium in silicate melts at alumina-iron spinel saturation is strongly increasing as a function of the prevailing oxygen activity. Thus, over the entire oxygen partial pressure range studied, it was dissolved as an oxide species in the molten iron silicate melt.

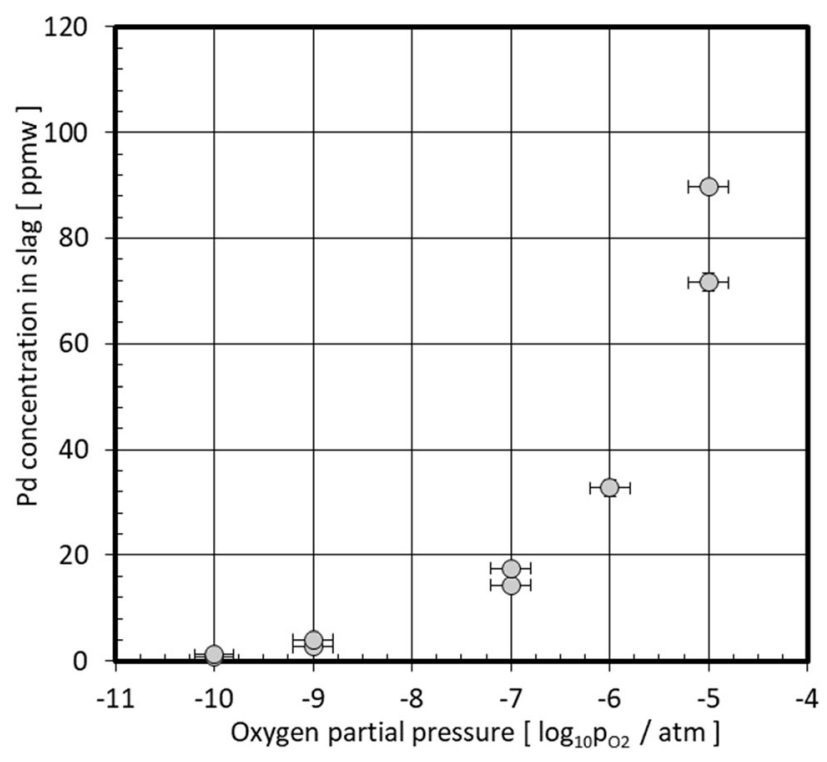

Fig. 3. Concentration of palladium in alumina-iron spinel saturated iron silicate melts as a function of oxygen partial pressure at $1300^{\circ} \mathrm{C}$, in equilibrium with solid iron-palladium alloy.

Selected experimental points were measured from the solid alumina-iron spinel phase and its palladium concentration in equilibrium with the molten slag. The spinel was essentially a binary solution of $\mathrm{FeAl}_{2} \mathrm{O}_{4}$ and $\mathrm{Fe}_{3} \mathrm{O}_{4}$, as its silicon concentration at the studied oxygen partial pressure range was very low, between 0.035 and 0.055 wt.\% (Si), equivalent to 0.075 and 0.12 wt.\% $\mathrm{SiO}_{2}$. The obtained distribution coefficient of palladium between liquid slag $(s)$ and solid spinel (sp), $L^{s / \mathrm{sp}} \mathrm{Pd}=\left(\begin{array}{lll}\text { wt.\% } & \mathrm{Pd}\end{array}\right)_{\text {slag }} /$ (wt.\%Pd $)_{\text {spinel, }}$, shows a minor enrichment in the spinel at $p_{\mathrm{O} 2}=10^{-6}-10^{-5}$ atm with $L^{s /}$ ${ }^{\mathrm{sp}}(\mathrm{Pd})=0.45 \pm 0.2$.

The apparent distribution coefficient of palladium between the metal alloy and molten silicate has been defined conventionally ${ }^{27}$ as:

$$
L^{a / s} \mathrm{Pd}=[\mathrm{wt} . \% \mathrm{Pd}]_{\text {alloy }} /[\mathrm{wt} . \% \mathrm{Pd}]_{\text {slag }}
$$

where $[\% \mathrm{Pd}]_{\text {alloy }}$ and $(\% \mathrm{Pd})_{\text {slag }}$ are the concentrations of palladium in the corresponding phases. The functional relationship between $L$ and the oxygen partial pressure can be obtained using the oxidic dissolution reaction of palladium in the slag, which can be written as:

$$
[\mathrm{Pd}]_{\text {alloy }}+x / 2 \mathrm{O}_{2}(g)=\left[\mathrm{PdO}_{x}\right]_{\text {slag }}
$$

where $x$ refers to the oxidation degree of the palladium oxide present in the molten slag. The dissolving palladium in Eq. (3) was written as an alloy, due to dissolution of iron from the slag. Using the equilibrium constant equation of Eq. (3) combined with the apparent distribution coefficient $L^{a /}$ ${ }^{s} \mathrm{Pd}$ in Eq. (2), the reorganized form for the thermodynamic distribution coefficient ' $L^{a / s} \mathrm{Pd}$ is: 


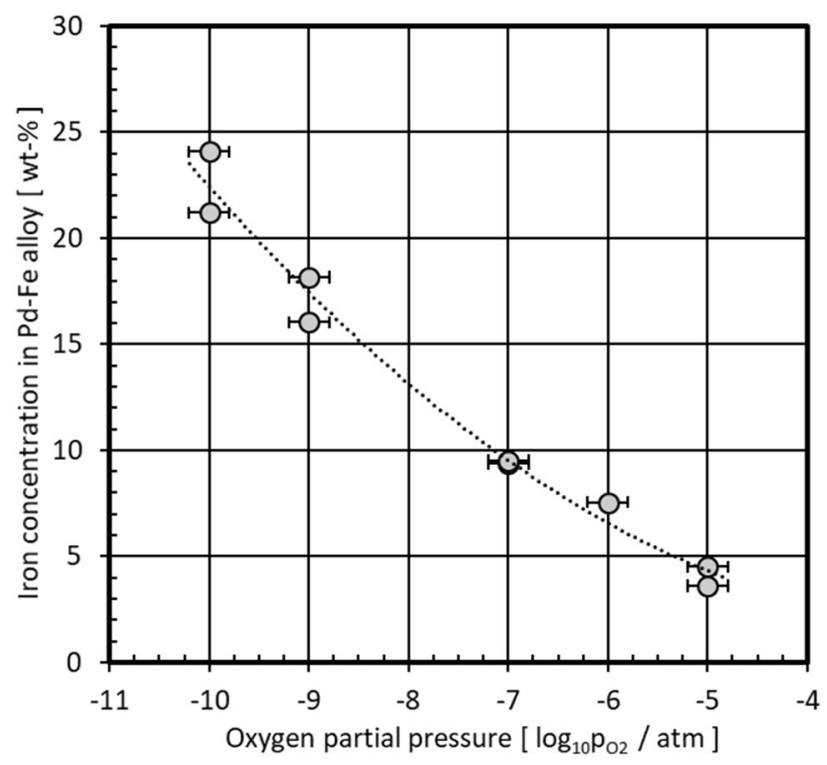

Fig. 4. The measured (EPMA) iron concentration in the solid ironpalladium alloy as a function of the oxygen partial pressure at $1300^{\circ} \mathrm{C}$.

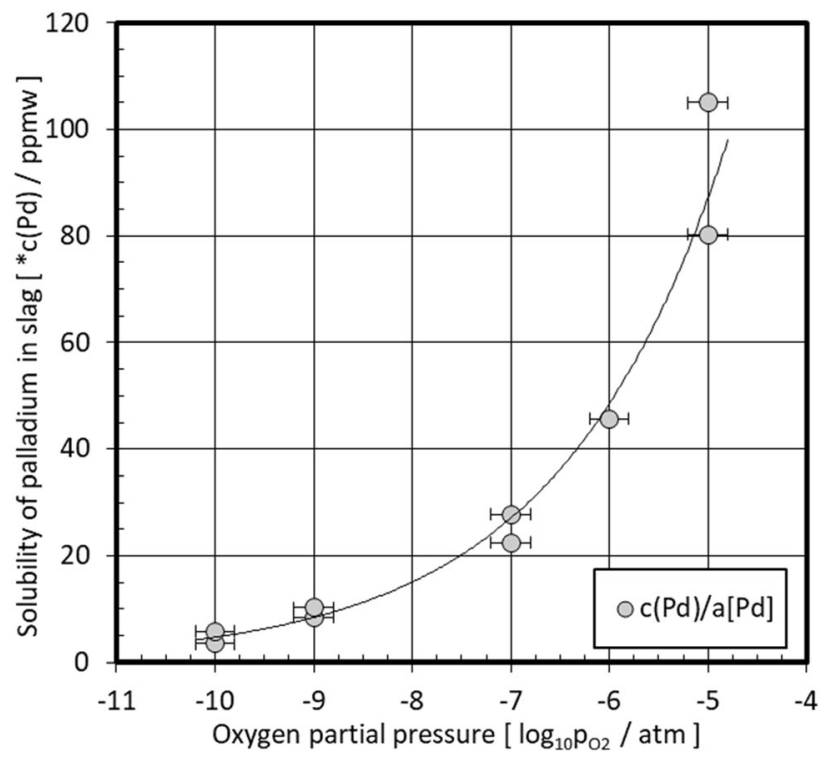

Fig. 5. The chemical solubility of palladium in alumina spinel saturated iron silicate melt as a function of the oxygen partial pressure at $1300^{\circ} \mathrm{C}$.

$$
\begin{aligned}
\log ^{\prime} L^{a / s} \mathrm{Pd}= & \log L^{a / s} \mathrm{Pd}+\log \left\{f[\mathrm{Pd}] / n^{\mathrm{T}}[\text { alloy }]\right\} \\
= & \log \left[1 / K \cdot f\left(\mathrm{PdO}_{x}\right) / n^{T}(\text { slag })\right]-x / 2 \\
& \cdot \log p_{\mathrm{O}_{2}} .
\end{aligned}
$$

In this case, the composition of the palladium alloy, the activity coefficient of palladium $f[\mathrm{Pd}]$, as well as the number of moles in the alloy, $n^{\mathrm{T}}$ [alloy], vary so significantly that they must be taken into account when calculating the oxygen activity slope of the metal-slag distribution coefficient. In Eq. (4), the symbols $n^{\mathrm{T}}$ (slag) and $n^{\mathrm{T}}$ [alloy] refer to the number of moles in $100 \mathrm{~g}$ slag and alloy, respectively, $K$ is the equilibrium constant of Eq. (3), and $f[\mathrm{Pd}]$ and $f\left(\mathrm{PdO}_{x}\right)$ are the Raoultian activity coefficients of palladium in the solid alloy and palladium oxide in the silicate melt, respectively. The obtained concentrations and activity data of palladium ${ }^{13}$ allowed us to estimate the dissolving oxide form of palladium in the slag according to the thermodynamic distribution coefficient derived in Eq. (4) and presented in Fig. 6. Additionally, the apparent distribution coefficient and reference studies are included in Fig. 6.

According to Eq. (4), the oxidation mechanism of palladium or the oxidation degree in the slag can be obtained from the slope of $\log { }^{\prime} L^{a / s} \mathrm{Pd}$ versus $\log p_{\mathrm{O} 2}$ plot. The slope of the line was constant at 0.25 over the entire oxygen partial pressure range studied, as shown in Fig. 6. This suggests that the dissolving oxide species of palladium in the slag was $\mathrm{PdO}_{0.5}$ or that palladium was present in the molten iron silicate as a monovalent cation $\mathrm{Pd}^{+}$. This agrees with our previous studies ${ }^{5,6}$ in the copper-slag system, where the palladium form in slags was evaluated to be $\mathrm{PdO}_{0.5}$. Moreover, the observed oxidation mechanism of this study is in good agreement with the measurements of Borisov and Palme $^{28}$ and Laurenz et al. ${ }^{29}$ Thus, no further discussion about the presence of $\mathrm{Pd}^{\circ}$ at present oxygen partial pressures as delivered by Sullivan et al. ${ }^{1}$ is necessary for iron-rich silicate slags. The relatively high palladium concentration $(\sim 100$ ppm) found in the iron silicate slag at high oxygen partial pressures suggests reducing the slag cleaning conditions for successful palladium recovery. This may be related to the high stability of palladium oxide (standard Gibbs free energy of formation) at elevated temperatures. ${ }^{5}$ All the reference studies in Fig. 6 present distribution coefficients of palladium between copper and different slags, except for the geological study by Borisov and Palme. ${ }^{28}$

Yamaguchi $^{8}$ and Nishijama and Yamaguchi $^{2}$ reported copper-slag distribution coefficients for Pd which were approximately 1.5 orders of magnitude lower in logarithmic scale than the values obtained in the present study. The data by Shuva et al. ${ }^{3}$ at $1300^{\circ} \mathrm{C}$ suggested much higher palladium solubility in the slag and a strong influence of $\mathrm{MgO}$ concentration as well as of the slag basicity $(\mathrm{CaO}+$ $\mathrm{MgO} / \mathrm{SiO}_{2}$. The technique used in those studies was a bulk analysis by ICP-atomic emission spectroscopy of the slag where metal entrainment in sampling may cause major errors. Thus, in the cases of a high metal-to-slag distribution coefficient ( $>100$ ) the trace element concentrations in the slag can be seriously distorted. In the above cases, ${ }^{2,3,8}$ the distribution coefficients reported were 1.5-2 orders of magnitude in log scale smaller than obtained in this study, where true chemically 


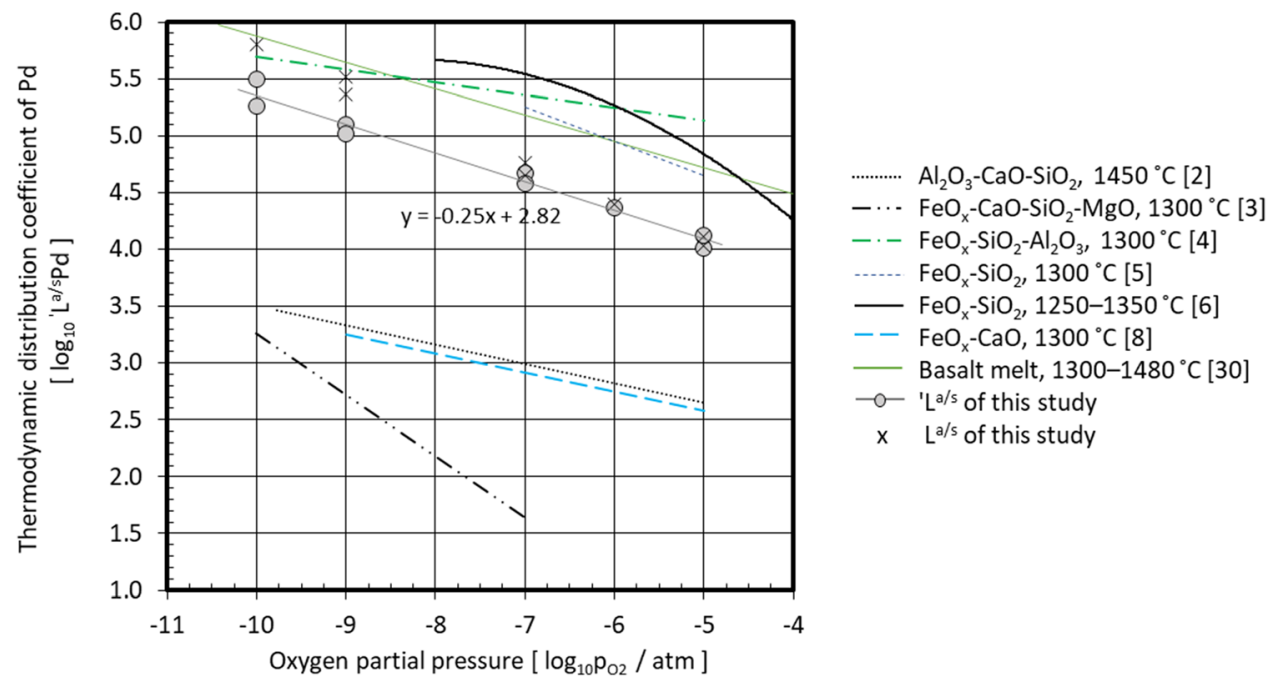

Fig. 6. The thermodynamic distribution coefficient of palladium between pure metallic Pd and molten iron silicate slag saturated with solid alumina-iron spinel at $1300^{\circ} \mathrm{C}$. The apparent distribution coefficient values obtained in this study, as well as results of several earlier studies, have been plotted for comparison.

dissolved concentrations were measured by direct phase analyses of the glassy silicate phase without the need for mechanical phase separation.

The distribution coefficients of Pd between copper and iron silicate slag at $1300^{\circ} \mathrm{C}$ by Avarmaa et al. ${ }^{5}$ and Sukhomlinov et al. ${ }^{6}$ are slightly higher than the ones obtained in this study. The values obtained by Avarmaa et al. between copper and high-alumina iron silicate slag ${ }^{4}$ correspond to the present values in reducing conditions but are also slightly on the higher side in oxidizing atmospheres. A comparison of the present experimental solubilities of palladium with geochemical data from low-iron basaltic silicates at $1300-1350^{\circ} \mathrm{C}$ and 1 atm total pressure by Sullivan et al. ${ }^{1}$ and Borisov and Palme ${ }^{28}$ are in good agreement with the values obtained in this study at $1300^{\circ} \mathrm{C}$. The distribution coefficients of $\mathrm{Pd}$ between pure $\operatorname{Pd}(a=1)$ and basalts were slightly on the higher side in oxidizing conditions but similar to our results in reducing conditions. ${ }^{1,28}$

The influence of copper on the distribution coefficient of palladium has been small when compared to our previous studies ${ }^{4-6}$ in copper-saturated systems, as the distribution coefficients obtained previously were of the same order of magnitude despite the presence of metallic copper, especially in the reducing conditions. Additionally, this study clarifies the behavior of palladium at reducing, lowoxygen partial pressure conditions, in which the concentrations in slags at copper saturation were previously below the detection limits of LA-ICPMS. ${ }^{4,6}$ Here, we have also provided strong evidence that with $\mathrm{FeO}_{x}-\mathrm{SiO}_{2}-\mathrm{Al}_{2} \mathrm{O}_{3}$ slags containing copper, palladium results can be presented according to concentration results achieved with isotope ${ }^{104} \mathrm{Pd}$ or with corrected results by isotopes ${ }^{106} \mathrm{Pd}$ and ${ }^{108} \mathrm{Pd}$. Nevertheless, when new systems containing additional elements are characterized with LAICP-MS, all possible isobaric interferences need to be considered and carefully examined.

\section{CONCLUSION}

Palladium is a critical element of the EU, the availability of which in the future needs to be secured. This study provided new insights to its behavior, recyclability, and recoverability via ferrous and non-ferrous smelting conditions. In order to confirm the solubility of palladium in aluminarich iron silicate slags, an experimental series was completed with direct contact between palladium and the slag. The experimental conditions were typical copper and nickel smelting/converting as well as slag cleaning conditions at $\mathrm{p}_{\mathrm{O} 2}=10^{-5}$ to $10^{-10} \mathrm{~atm}$ and $1300^{\circ} \mathrm{C}$. The obtained results formed a coherent dataset with a constant thermodynamic distribution coefficient versus the $\mathrm{p}_{\mathrm{O} 2}$ slope of 0.25 , indicating a solution of $\mathrm{Pd}$ as the $\mathrm{PdO}_{0.5}\left(\mathrm{Pd}^{+}\right)$form in slag, for the metal-slag distribution coefficient between $10^{4}$ and $10^{5.5}$.

\section{ACKNOWLEDGEMENTS}

Financial support by CMEco (Grant \# 7405/31/ 2016) and SYMMET (Grant \# 3891/31/2018) programs of Business Finland are gratefully acknowledged. Additional funding from the Alfred Kordelin Foundation, Finnish Cultural Foundation as well as the Emil Aaltonen Foundation (KA), and the Finnish Steel and Metals Producers' Fund (LK) is also appreciated. The EPMA measurements were carried out by Mr. Lassi Pakkanen of the Geological Survey of Finland. This study utilized the Academy of Finland's RawMatTERS Finland Infrastructure (RAMI) housed at Aalto University, GTK and VTT. 


\section{FUNDING} sity.

Open access funding provided by Aalto Univer-

\section{CONFLICT OF INTEREST}

On behalf of all authors, the corresponding author states that there is no conflict of interest.

\section{OPEN ACCESS}

This article is licensed under a Creative Commons Attribution 4.0 International License, which permits use, sharing, adaptation, distribution and reproduction in any medium or format, as long as you give appropriate credit to the original author(s) and the source, provide a link to the Creative Commons licence, and indicate if changes were made. The images or other third party material in this article are included in the article's Creative Commons licence, unless indicated otherwise in a credit line to the material. If material is not included in the article's Creative Commons licence and your intended use is not permitted by statutory regulation or exceeds the permitted use, you will need to obtain permission directly from the copyright holder. To view a copy of this licence, visit $h$ ttp://creativecommons.org/licenses/by/4.0/.

\section{SUPPLEMENTARY INFORMATION}

The online version contains supplementary material available at https://doi.org/10.1007/s11837021-04672-4.

\section{REFERENCES}

1. N. Sullivan, Z. Zajecz, and J. Brenan, Geochim. Cosmochim. Acta 231, 15. (2018).

2. W. Nishijima, and K. Yamaguchi, J. Jpn. Inst. Metals Mater. 78, 267. (2014).

3. M. Shuva, M. Rhamdhani, G. Brooks, S. Masood, and M. Reuter, Metall. Mater. Trans. B 48B, 317. (2017).

4. K. Avarmaa, H. O'Brien, L. Klemettinen, and P. Taskinen, J. Mater. Cycles Waste Manag. 22, 642. (2020).

5. K. Avarmaa, L. Klemettinen, H. O'Brien, and P. Taskinen, Miner. Eng. 133, 95. (2019).

6. D. Sukhomlinov, L. Klemettinen, K. Avarmaa, H. O’Brien, and P. Taskinen, Metall. Mater. Trans. B 50B, 1752. (2019).
7. K. Yamaguchi, in Proc. Extraction 2018, ed. by. B. Davis, M. Moats \& S. Wang (Ottawa, Canada, August 26-29, 2018) (Springer, TMS Warrendale (PA), 2018), p. 797.

8. K. Yamaguchi, in Proceedings of the 6th European Metallurgical Conference (EMC2011), (Düsseldorf, Germany, June 26-29, 2011) (GDMB, Clausthal-Zellerfeld, 201), p. 171.

9. H. Henao, K. Yamaguchi, and S. Ueda, in Proc. Sohn Int. Symp. ed. by F. Kongoli \& R.G. Reddy (San Diego, US, August 27-31, 2006) (TMS, Warrendale (PA), 2006) p. 723.

10. K. Avarmaa, H. O'Brien, H. Johto, and P. Taskinen, J. Sustain. Metall. 1, 216. (2015).

11. P. Piskunen, K. Avarmaa, H. O'Brien, L. Klemettinen, H. Johto, and P. Taskinen, Metall. Mater. Trans. B 49B, 98. (2017).

12. J. Tomiska, Thermochim. Acta 535, 42. (2012).

13. G. Ghosh, C. Kantner, and G. Olson, J. Phase Equilib. 20, 295. (1999).

14. M. Guillong, L. Danyushevsky, M. Walle, and M. Raveggi, J. Anal. At. Spectrom. 26, 1401. (2011).

15. M. Benson, C. Bennett, J. Harry, M. Patel, and M. Cross, Resour. Conserv. Recycl. 31, 1. (2000).

16. L. Klemettinen, K. Avarmaa, H. O'Brien, A. Jokilaakso, and P. Taskinen, JOM 72, 2770. (2019).

17. L. Klemettinen, K. Avarmaa, and P. Taskinen, J. Sust. Metall. 3, 772. (2017).

18. L. Klemettinen, K. Avarmaa, A. Jokilaakso, and P. Taskinen, J. Alloys Compd. https://doi.org/10.1016/j.jallcom.2020. 157539 (2020).

19. K. Jochum, U. Weis, B. Stoll, D. Kuzmin, Q. Yang, I. Raczek, D. Jacob, A. Stracke, K. Birbaum, D. Frick, D. Günther, and J. Enzweiler, Geostand. Geoanal. Res. 35, 397. (2011).

20. K. Jochum, M. Willbold, I. Raczek, B. Stoll, and K. Herwig, Geostand. Geoanal. Res. 29, 285. (2005).

21. E. van Achterberg, C. Ryan, S. Jackson, and W. Griffin, Laser Ablation ICP-MS in the Earth Science: Principles and Applications, Short Course Series \#29 (Mineralogical Association of Canada, St John, Newfoundland, 2001), p 239.

22. K. Jochum, U. Weis, B. Stoll, D. Kuzmin, Q. Yang, I. Raczek, and D. Günther, Geostand. Geoanal. Res. 35, 397. (2011).

23. N. Sugiyama, and Y. Shikamori, J. Anal. Atom. Spectrom. 30, 2481. (2015).

24. P. Sylvester, Laser-Ablation in the Earth Sciences: Principles and Application (Mineralogical Association of Canada, 2001), p 203.

25. IUPAC Periodic Table of Elements and Isotopes, https://w ww.isotopesmatter.com/applets/IPTEI/IPTEI.html Accessed on 4 Dec 2020.

26. V. Malavergne, E. Charon, J. Jones, P. Cordier, K. Righter, D. Deldicque, and L. Hennet, Earth Planet. Sci. Lett. 434, 197. (2016).

27. A. Yazawa, Erzmetall 33, 377. (1980).

28. A. Borisov, and H. Palme, Mineral. Petrol. 56, 297. (1996).

29. V. Laurenz, R. Fonseca, C. Ballhaus, and P. Sylvester, Geochim. Cosmochim. Acta 74, 2989. (2010).

Publisher's Note Springer Nature remains neutral with regard to jurisdictional claims in published maps and institutional affiliations. 